A TRANSIATION OF LORCA'S "EI PUBIICO"

Thomas Earl Barden

Richmond, Virginia

B.A. University of Vinginia, 1968

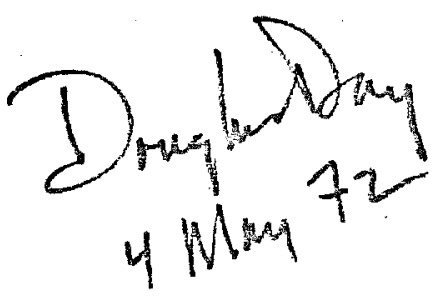

A Thesis Prezented to the Graduate

Faculty of the University of Virginia in Candidacy for the Degree of Naster of Arts

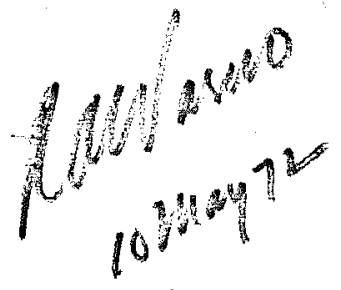

Department of English

University of Virginia

June, 1972 


Masters
English
1972
BS
copy 2


Introduction

The Audience vas vritten during a period of transition - for Carcía Lorca. He began the play in New York or Havana in either 1929 or 1930 . He was working on another experimental play called If Five Years Pass (Asi que pasan cinco axos) at the sane time. Both of these plays show a novenent in the direction of surrealism, but the acts available from The Audience (El Publico) constitute Lorca's most sustained surrealistic effort.

Manuel Duran, ir his introduction to Lorca: A Collection of Critical Essays (Englewood Cliffs: Prentice-Hall, 196́2, pp. 6-10.) divides Lorce's work into four periods. The first, he says, is "a suodued, nostalgic style, inspired party by Ranón Jiménez." The second period is "a personal style, based on a fusion of traditional and dramatic subjects and new metaphors. ... In them images are very important. Up to the New York period Lorca was to emphasize them." Of the third period, the one in which the Audience-was written, Duran says, "Chaos and anguishreign inside the poet's heart as they rule the outside world as he sees it... Gonez de la Sema was not the only innovator whose work Lorca had assimilated: in Madrid there lived or had Iived Vicente Huidobro, Juan Iarrea, Gerardo 
Diego, and especially Salvador Dali, all of them influenced by Imagism, Dadaism, and Surrealism," The value of The Audience, then, is as the most representative work of Lorca's surreal period. This period influenced the drama of the last and most noted period, which Duran describes as a return to "traditional and Spanish subjects.". The last period is that of Blood Vedding and Yerma.

Lorca and his friends attached a great deal of importance to the surreal plays (See note, p. 144 of Collected Essays). In fact, in Robert Iima's The Theater of Garcia Lorca (New York: Las Americas, 1963, p. 161,), Lorca is quoted as saying

I have followed a vell-defined trajectory in the theater. My first plays are unpresentable. Now I believe that one of them, It Five Years Pass, will be presented by the club Anfistora: hy goal is in these impossible comedies. But in order to demonstrate a personality and be worthy of respect, I have done other things.

Perhaps, had Lorca lived, plays like these, and especially the Audience, would have becone more important to Lorca scholars. Act III, scene $i$, of Blood liedding, with its surreal character, "The Moon", and the old beggar woman who is death, gives an indication of the uses to which Lorca might have put surrealism, At least we can see how he actually did use the style by looking at the two available acts of the Audience.

The portions of the play which are translated here are not the only existing pieces of the play. There are remants 


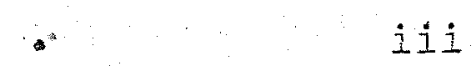

of the other three acts which are unavailable for translation, Before looking at the two published acts, a genenal description of the other three will be helpful. Rafael Martiner Nadal, in his book El Publico: Anon, teatro y caballos en la obra de Foderico Garcia Lorce (Oxford: Dolphin, 1970.) gives an analysis of the acts which were not printed in Ios Cuatro Vientos in Madrid in 1934. These nanuscripts mere available to Nadal when he made his study. I shall translate in paraphrase.

-- The first act introduces three bearded men and the stage director. One of the three men is intent on 'unmasking' the director. A female character. Elene, is introduced in some indeterminable connection with the director. The bearded men are revolutionaries of a surreal sort; they have a bomb which can reveal the true nature of people. The symbolic horses are intr duced in this first scene. They repeat the phrase "Misericordia" (Have mercy!) throughout the act. Wany of the images and phrases which occur later are introduced here, e.g. "One is one and always one." The act ends with the horses saying

\section{Mercy! Mercy!}

The horses are sounding their giant trumpets,

The people are all rigid in their places.

\section{-- Slow Curtain --}

The second act is the one translated as "The Roman queen", although Nadal tells us that the manuscript reads 'ruina' and 


\section{iv}

not 'reina', so that the correct title is "The Roman Ruins". This correction makes sense considering that the setting is in fact Roman ruins.

- The unnumbered act is the one Nadal cites as the most problenatic. The set is a large white backdrop, which leads to the argument that this was Iorca's first act. There is a reference in "The Romen Ruins" to the white screen of the first act. Whatever the order, this act is nighly imagistic and symbolic. It introduces the situation which is the crux of "The Fifth Act", the playing of Romeo and Juliet. The setting is beneath the arena, which seens synonymous with the subconscious or the 'id', in which such dramatic subjects as love and death and fear are acted. There are green screens and gelatin noons across the white screen, giving an Alice in Wonderland' mood to the scene. The horses speak indiridually in this act, as opposed to thein chorlis lines before. They are differentiated at this point as to color, black or white. A discussion of the bearded men begins the act; their homosexuality (and the director's) is implied, The men discuss who might have killed the Roman emperor. The director and the men take up the metamorphosis motif of the two figures in the ruins. Ballerina's and harlequin's clothing are given to the director, and here it becomes obvious that the director is to be the ballerina named Guillemina, the harlequin named Henry, and that he was the figure in tendrils. The set takes on a puppet 
show aura at this point. It is stated that one of the men will play Juliet in the drama.

The fourth act is titled "The Fifth Act" and is presented here in translation.

-- The last, act is set like the first with the exception that there is a gigantic horse's head to the left sicle of the stage, and a group of trees and some clouds leaning against a wall on the right. The director enters with a magician. This act has the tone of an epilogue. We learn that the doors of the theater have been broken. The stage director tells the magician that what has gone on inside the theater expresses what goes on every day in the cities and in the country. Then he adds that though they may have raised the curtain on truth, they have filled the seats with blood from the beginning. In this epilogue act a woman dressed in black and her maid are intruluced. The woman is in search of her son Gonzalo. The magician takes the role of death; he tells her her son is. dead. At this point the maid notices the audience and tells the director that there are people watching them. "The director cannot understand what she means. Then the magician gets on the horse's head, gestures, and disappears. The director has the last line, which is, "what is happening?"

Exactly what is going on in this work is indeterminable without the complete text, and perhaps even with it; however, 
it is possible to follon sone of the elements of the tho complete acts in light of this outline of the rest. It is obvious that the images used in this dialogue are poetic ones. Iorca's brother Francisco, in the introduction to Three Tramgedies (New Yonk: New Directions, 1955, p. 7.) telis us that Lorca's "theater springs from the same fountains as his lyric poetry ..." And we should reep in mind the fact that this play is basically poetic drama as ve read it.

The first act presented here begins with two neutral figures exchanging dialogue in a setting of Roman ruins. One of them is covered in gilded bells and the other in vine-like tendrils. We should note that Lorca was trying to find new metaphors and images in both his poetry and his plays at this time. John Croy was a fellow student of Lorca's at Columbia who writes in Duran's introduction (Collected Essavs, 2.7.)

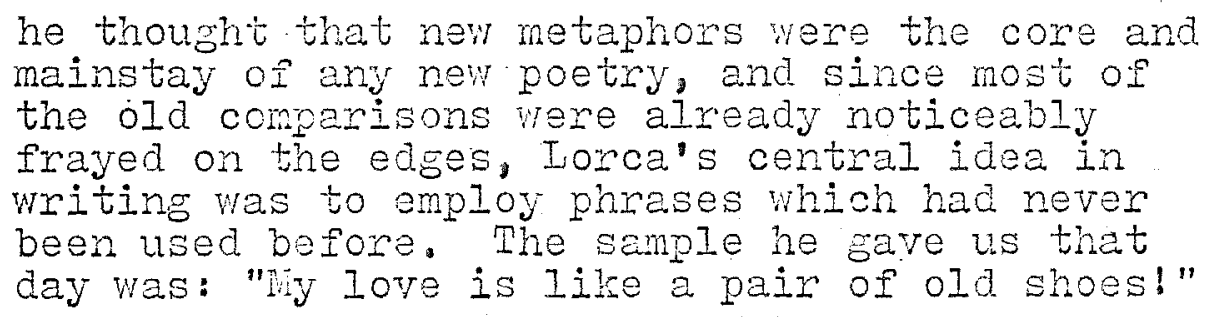

So the bells and the vines are open to interpretation. Since, the subject of the dialogue is netamorphosismm "If I should change into a ____ I would change into a ." it is likely that the belis and the vines are merely forms. In fact, at the end of the act, one of the figures sheds his tendrils to become a white plaster mude. The bells and the fact 
that this figure is dancing sugests thet he represents the artist. But when we consider thet he is juxtaposed to a figure who is the director in disguise, presumably the artiet figure, we begin to associate the figure in bells with art itself. He is a frustrating muse for whom the emperon is cearching and with whom the figure in tendrils is strugring in a negation of love. Iima sees the conversation as follons (p. 22.):

Cruelty and devotion seesait on the frail ful crum which divides fantasy and reality, each

figure in tum adopting both expressions.

Many concepts are touched on in this conversation. The constant references to violence and implements of violence contrast to the constant references to love. Perhaps the nost typical of these paradoxical references is the speech in which the figure in belis says he is such a heman he can brekk rocks with the fingernails of a new-born baby. This spech is discussing sensitivity, the sensitivity that the antist learns from art which enables him to comprehend the "theater under the arena." When the Roman emperon, a symbol of man's rrustrated search for unity, appears, the figure in bells (art, on the concept of artist) plays the role of the vine figure. The emperor finds the unity he is looking for in the form of the real (?) rine figure who has been hiding in the ruins, The vine figure transforms himself into the nude object of the emperor's search, they embrace, and the bell figure cries out (along with the director who enters at the very end) that he 
has been betrayed.

There are many possibilities for interpretation in the major surreal imeges in this act. The ruins could represent "the past" or histony or tradition. That the art versus artist conflict (or love-maring) takes place there would follow Lorca's feelings for the traditions of the past as the crucible of creation which new art must contend with and alter. The ability, on necessity, to deal with metamorphosis is a standard surreal aesthetic. Angel del Rio, in his article "Lorca's Theater" in Duran's collection ( $p, 145$.$) , says, "This is the$ idea which inspired some of the poens of Poet in New York. It reminds us especially of "Death": "What an effont, what an effort of the hoxse/ to become a dog,". From Nadal's fragments we see that the metamorphoses are very convoluted and that there are mesks on masks on masks at many points during the play. The convolutions sme to be almost the center of the play when we realize that most of the characters can be reduced to the director, Nlene (the moon and the real unity), and the magician, who is death. In a way the play, is a oneman-show of the director and his personified artistic concepts. His only company is the audience, which on one level becomes involved, but on the outside level is us, the truly passive watchers.

The other scane, "The Fifth Act", is also set in what finaliy appears to be the mind of the director, although at 
times we feel it is a real theater under an arena with the exits blocked, on a surrealistic railroad train, on both. One of the centers of this act, the old nude, which Nadal calls the red nude' due to his reading of Iorce"s handwriting, is an obvious Christ figure. He is so obviously one that we feel that he must be more than that. Perhaps he is the concept of unity which Christ gave to the world, but which has degenerated to the status of a sick old nude with a themometer (technology?) in His mouth (or perhaps it is a rectal themometer). A disdain for present-day religion is conveyed, but not a disdain for religion or mystical experience itself. Both scenes inply a quest for a religious vision.

The other main event in this act is the dual presentation of Romeo and Tuliet, and the revolution which follows this.

- There is an audience, perhaps the audience of the titre, which revojts when it is discovered that Juliet is a young boy, The historical fact of the Elizabethan practice is alluded to here, as is a question of suspension of disbelief, and, ultimately, the nature of reality. The subtlety of the interior play and the audience's reaction to it are discussed by members of the audience and a group of students, two of whon escape the university and run into the theater shouting "joy." These tro students admit to being in love, and two members of the trapped audience move in this direction as well. If one gets pleasure from discovering phallic symbols in order to assert that this play is obsessed with homosexual love, there is of course 
ample opportunity. It is apparent, howerer, that Ionca's treatment of love should de ween as more compley than merely homoserual, and that at least part of the use of the theme is to demonstrate the audience's (both audiences"!) bondage to stifling moral and social codes.

The horses are symbols of vitality, action, and life force. The students represent conscious intellect. The theater is the subconscious mind and creativity, and the obvious drives that irrevocably rule then both. The players reject the audience's negative reaction to any aberration of their accepted values. In fact, in these two scenes almost all of Lorca's most enphasized dramatic themes are considered.

The theme of the frustrating nature of tradition and som cial law is emphasized. The cause of the destruction of the relationship between the bell and the tendrit figures is their failuce to overcome preconceptions of themselves and their roles. The audience's failure to accept the play causes revm olution, blood, and chaos. The inability of the women to escape from the representative 'theater" is perheps a symolic statement of the sane theme. The horses are envied by those who cannot get out of the theater; they escaped through the roof and ran up the hillside with the director. The students, when they adnit their love for each other, decide to "smash" everything. They decide to strike back at the social strictures which have frustrated thein love.

The theme of life and death is apparently not developed 
until the epilogue act, when death bestrides the horse's head (Iife) and suddenly disappears. A very related question, that of reality is developed in these acts. It is the emphasis on this question, "What is reality?" that makes The Audience so strikingly different from Lorca's better known plays, the old nude as Christ, or unity, figures in this consideration as well. Any realistic study or drama must assume one simple premise-- that the things considered do in faot exist. To a primitive mind this poses no problem; to a believing mind it is no problem. It is the skeptical mind which begins to formulate subtle questions as to the reality of everything around. it. I think it was this consideration which led Lorca to primitivism in his last plays. Bernarda. Alba does not doubt any of her beliees, nor does Yerma, nor the bride. Here Lorca could deal wth social and pychological problems in characters to whom reality was assumed automatically. To one with a religious vision there is also no reality question. Rationality (intellect) is overcome by vision, by belief. Lorca's use of Christ in the Audienoe demonstrates reality, becoming chaos as the personification of the unity concept dies.

The result is total skepticism beyond the artist's own mind. The theater's cerebral nature substantiates this idea. The presence of constantly changing discuises and masks indicate that the real has become arbitrary. Under the influence of this skepticism metamorphosis is possible at will; the mood of the play becomes dream-like; and the only solution to the 
uncertainty of a Iack of 'the real' is emotional comitment. one can choose to love and to believe, thereby triumphing over intellect, chaos, and loss of unity. Surrealism is the obvious and perhaps only nethod through which this sort of statement can be made.

The theme of the cerebral nature of drana is a 'spin-off' of the reality thene. The fact that the play is called the Audience and that it ends with the players acknowledging us, the external audionce, is characteristic of what Lionel Abel in Metatheater (New York: Hill and Wang, 1963.) calls an aspect of all reality-questioning drama. Abel says that this drana is alvays self-amare, thet the characters are actors, and that they know they are watched by an audience whose reality is different from their om. The confusion about a real. Juliet under the seats of the theater and another Juliet on the stage suggests the Pirandellan idea that the Juliet in our minds is as real as any specific Juliet that ever comes on stage.

There is of course much more than this in The Audience, but these themes are some things to look for initially. There is enough in just these two translated acts to refute Edward Honig's statement in Garcia Lonca (Norfolk: New Directions, $1944, \mathrm{p} .150$.$) , thet$

of the two vorlds of dranatic possibility which Lorca was exploring at the time, the folk and the surrealist, it was fortunate that after leaming the Iimitations implicit in the second, he decided to occupy himself exclusively with the first. 
Who can say where Lorca"s experinents in surrealism might have - Ied hin? I think reading the following translation will show that, while he was still leaming the style of surrealistic theater, Iorca brought to The Audience a talent which, had it been allowed to live, might have given us surrealistic and poetic drana which would pale the too scanty ranks of this dramatic style. 
The Translation

The following translation corresponds to the Spanish text as given in Aguilan's obras Completes de Foderico Garcia Lorca. The translation is as literal as possible mithout sacrificing the meaning of the lines: The problems of textual nature, a few of which are mentioned in the introduction (pp. iii, and ix.), have not been considered due to inability to see Nadal's manuscripts! The overall sense of the two acts is probably uraltered. I refer Spanish speakens to Nadal's book for a clarification of sone of the mystery surrounding the manuscripts of The Audionce. 
(Scenes from a drama in five acts- 1933)

The Roman Queen'*

A figure covered with red tendrils is seated atop the capital of a colum playing a flute. Another figure covered with small bells is dancing at the center of the stage.

The Figure covered with bells--

If I should change into a cloud...

The Figure covered with tendrils--

Then I would change myself into an eye.

The Figure in bells--

If I should change into a turd.

The Figure with tendrils--

Then I would change myself into a fly.

The Figure in bells--

If I should change myself into the tail of a comet. The Figure with tendrils--

Then I would change into a kiss. The Figure in bells--

If I changed myself into a breast?

The Figure with tendrils--

I would become a snow-white bedsheet.

A. Voice (Sarcastically)--

Bravol

* or The Roman Ruins. See introduction p. v. 
The Figure in bells--

What if I should change into a moon-fish?

The Figure with tendrils--

I would change into a knife.

Figure in bells (Stops dancing) --

A knife! A knife? Why do you toment me so? If you love me, why can't you go along with me even when I get carried away? If I change into a moon-fish, you should change into a wave on the ocean, or a clump of seaweed. Or if you wish, something more distant, if you don't want to kiss me, change into a full moon. But a knife! You just enjoy mining my dance. And my dance is the only way I have of loving you.

Figure with tendrils--

I'Il go along around the bed and the fumiture with you, but I won't go every way you so wisely want me to. If you were to tum into a moon-fish, I would open up a knife... because I am a man. Because I am more of a man than Adam. And I want you to be more of a man even than I. I want you to be such a man that the wind in the branches of the trees falls silent when you pass. But you are not a man, and if I didn't have this flute you rould escape and run off to the moon. Off to the lace-edged moon all spattered with drops. of women's blood.

Figure in bells (Timidly) --

If I should change into an ant...

Figure with tendrils (Energetically) --

Then I would change myself into soil.

Figure in bells (Stronger)--

If I should change into soil? 
Figure with tendrils (Weaker)--

Then I would change into water.

Figure in bells (Vibrantly)--

And if. I became water?

Figure with tendrils (Fainting)--

I'd change into a moon fish.

Figure in bells (Treinbling) - -

What if I became a moon-fish?

Figure with tendrils (vaking up)--

I would become a knife! A knife sharpened four long seasons ago! Figure in bells-.-

Take me to the pond and drom me. That's the only way you'll get to see me naked. Do you really think I an afraid of blood? I know how to master you. Do you think I don't know you? I know you so well. I know if I say, "If I should change into a moon-fish." you will answer, "I would change into a sac of fish-roe."

Fic are with tendrils-o

Take an axe and chop off riy legs. Let the insects of the rubble come because I despise you. I want you to sink to the very depths. I spit on you.

Figure in bells--

You want that? Fine, that suits me. Farewell. If I descend into the depths of the rubble I shall find love there every time. Figure with tendrils (Worried)--

Where are you going? Where?

Figure in bells-

Didn't you tell me to go away? 
Figure with tendrils (In a weak voice)--

No, don't go away. What if I should change myself into a grain of sand?

Figure in bells--

I would change myself into a whip.

Figure with tendrils--

What if I changed into a sac of fish-roe?

Figure in bells--

I would still change into a whip, a whip made of guitar strings. Figure with tendrilsm

Don't whip me!

Figure in bells--

A whip made of ships' cables.

Figure with tendrils--

Don't whip me in the stomach!

Figare in bells--

A whip made of the stamen of an orchid.

Figure with tendrils--

You'd end up leaving me blind!

Figure in bells--

Blind, because you aren't a man. I, I am a man. I am such a man that I faint when the hunters wake. I an such a man that I get a knife-sharp toothache when someone picks the smallest flower. I am a giant. A giant! I am such a giant giant I can break rocks with the fingernail of a newborn baby.

Figure with tendrils--

I am waiting for the night. I am anguished by the white of these ruins. I'm waiting for a chance to crawl at your feet. 
Figure in bells-.

No, nol Why do you tell me that? You are the one who should force me to do that! Aren't you a man? Aren't you more of a man than Adarn?

Figure with tendrils (Falling to the ground) -

Ay! Ayee!

Figure in bells (Approaching him, in a low voice)-What if I should change into a colurn.

Figure with tendrils-.

Oh Dear God!

Figure in bells--

You would change into the shadow of a column, that's all. Then Elena, oh yes, Elena would come to my bed. You would be stretched out under the pillows covered with sweat. Not even your own sweat; It would be the sweat of coachmen, of boiler-stokers, of surgeons operating on cancers. And then I would change into a moon-fish and you would become a little fleck of dust floating around.

Figure with tendrils--

Again? Are you crying again? I shall have to faint so the peasants will come. I'll have to sumon the Negroes, the huge Negroes who are wounded by the cactus thorns and who struggle night and day with the mire and the mud of the rivers. Get up, you coward Iesterday I was in the foundary and I ordered a chain. Don't move away from me, you filthy Eve! And I cried all night because my wrists and ankles hurt. And I didn't even have the chain on. (The Figure with tendrils blows a silver whistle)

Figure in bells--

What are you doing?. (He blows the ishistle again) I know what you 
want, but I have tine to escape.

Figure with tendrils (Getting up)--

Escape if you want to.

Fisure in bells--

I shall defend myself with weeds.

Figure with tendrils--

Prove you'll defend yourself. (He blows the whistle) (A Boy

- dressed in a red net falls from the ceiling)

The Boy--

The emperor, the emperor, the emperor!

Figure with tendrils--

The emperor.

Figure in bells--

I'll pretend I'm you. Don't tell. It would cost ine my life. B०y--

The emperor, the emperor, the emperor!

Firclue in bells--

Everything between us was a game. We were playing. I'Il wait

on the emperor and mimic your voice. You can stretch out behind

that big column. You have never spoken to him... there is a cow

there cooking the meal for the soldiers.

Figure with tendrils--

The emperor; now it is too late. You have broken the spider's web.

I feel my big feet tuming small and grotesque again.

Figure in bells--

Would you care for a little tea? Where can one find a hot drink

in this rubble? 
Boy (On the ground) --

The emperor, the emperor, the emperor!

(A trumpet sounds and the Roman Enperor enters. A Centurion with

a yellow tunic and gray skin follows hirn. Behind them come four horsemen with trunpets. The Boy goes to the Enperor. Fe takes the Boy in his ams and they disappear behind the columns.)

Centurion--

The emperor is looking for one.

Figure with tendrils--

I am one.

Figure in bells -

I am one.

Centurion--

Which of you is one?

Figure with tendrils--

Me.

Fignre in bells--

Me.

Centurion--

The emperor will decide wich of you two is the one. With a spitball or a knife. Cursed be you and your fellows! Because of you I am walking the roads and sleeping on sand. Hy woman is as beautiful as the mountains. She gives birth four or five times, one after the other, and never at noon under the trees. I have two hundred sons. And I will have even more. Cursed be all of your class! (He spits and then sings)

(A loud sustained scream is heard from behind the column. The Emperor appears wiping his forehead. He takes off some black gloves, 
then red gloves to reveal the classic whiteness of his hands.)

The Emperor (Disagreeably)--

Which of you two is one?

Figure in bellsw-

I am sir.

Emperor-

One is one and always one. I have beheaded over forty young inen who didn't want to talk.

Centurion (Spitting)--

One is one, and only one.

Emperor--

And there are not two.

Centurion--

Because if there were two the emperor would not be searching these roads.

Emreror (To the Centurion)--

Strip then!

Figure in bells--

I am one sir. This fellow is the beggar of the ruins. He feeds on roots.

Imperor--

Move apart!

Figure with tendrils--

You know me. You know who I am. (He takes off his tendrils and. reveals himself as a white plaster nude.)

Emperor (Embracing him)--

One is one. 
Figure with tendrils--

And alvays one. If you kiss ine, I'll open my mouth so that you can drive your sword in my neck.

Emperor--

That shall be.

Figure with tendrils--

And leave my head full of love in the rubble. The head of one tho a] ways was one.

Emperor (Sighing)--

One.

Centurion (To the Emperor) --

It is difficult, but there you have it.

Figure with tendrils--

He has it because he could never have it.

Figure in bells--

Treason! Treason!

Cerourion--

Shut up you old rat! Son of a broomstick!

Figure in bells--

Gonzalo, help me, Gonzalo! (He pushes on a colum and it unfolds

into the witie screen from the first scene. Three bearded men and the Director enter from behind it.)

First Man--

Treason!

Figure in bells--

They have betrayed us!

The Director--

Treason! (The Emperor is embracing the Figure with tendrils.) 
The Fifth Act

In the center of the stage there is an upright cot showing the front view as in a primitive painting. In the cot there is a nude old man wearing a crown of blue thoms. In the background are the arches and stairs that lead to the box seats of a great theater. To the right there is the facade of a university. As the curtain rises there is a round of applause.

The Nude--

When will you finish?

A Viedic (Entering rapidly) --

When this tumult is over.

The Nude-m

What do they want?

The Medic--

They are asking for the death of the director.

The Nude--

What are they saying about me?

The Medic-s

Nothing.

The Nude--

What about Gonzalo? Is anything known about him?

The Medic--

They are looking for him in the mins.

The Nude--

Oh I.want to diel How many cups of blood have they bled me of? The Yiedic--

Fifty. I'll give you the gall now and then come back at eight o' clock 
with the scapel to lance that wound in your side.

The Nude--

The one that has more vitamins?

The Medic--

Yes.

The Nude--

Are they letting the people in the arena leave.

The Nedic--

On the contrary, the soldifols and the engineers are blocking all the exits.

The Nude=-

How long before we get to Jerusalem?

The Medic--

Three stations if there is enough coal left to make it. The Nude--

O Wy Father, let this cup of sorrow pass from me. The Hedic--

Oh shut up! This is already the third thermoneter you've broken. (The students enter. They are dressed in black academic robes with red trappings.)

1st Student-

Why don't we clean our weapons?

2nd Student--

The streets are full of armed men. It would be difficult to get away.

3rd Student--

What about the horses? 
5th Student--

The horses manazed to get away by breaking down the roof of the stage.

4 th Student $-\infty$

While I was confined to the tower I saw whole herds of them running up the hillside. They were with the stage director.

1st Student--

Doesn't the theater have a pit?

2nd Student--

The pit is barred to the crowd. It's better to stay here. (A round. of applause is heard. The Medic Iifts the old Nude up in the bed and arranges the pillows.)

The Nude--

I thirst.

The Medic--

I have sent to the theater for water.

4th Student--

The first bomb of the revolution grazed the skull of the rhetoric professor.

2nd student--

Much to the joy of his wife. She'll be working so hard now they'll have to put faucets on her nipples.

3rd Student--

They say a horse climbs upon her terrace every night.

1st Student--

She was the very one that saw the whole thing from a skylight in the theater and screamed out the warning. 
4 th Student--

And even though the poets got a ladder and tried to climb up and assassinate her, she kept on screaming and alerted the crowds.

2nd Student-o

What's her rame?

3rd Student--

Elena.

1st Student (Aside) $=m$

Selene.*

2nd Student (To the 1st Student) $-\infty$

What's the matter with you?

1st Student--

I'm afraid to go out.

(The Two Thieves cone down the stairs. Several women in evening

dresses suddenly appear in the theater boxes. The students discuss

this among thenselves.)

1st Woman-s-

Are the coacines still out front?

2nd Woman--

How horrible:

3rd Woman-

They have found the stage director in the sepulcher.

1st Woman--

What about Romeo?

4th Woman--

They were taking his clothes off when we left.

* Greek word mearizing 'the moon.' 
1st Young iian-..

The audience wants the poet dragged through the streets by horses. ist Woman--

But why? It was a delightful play. The revolution has no right to desecrate graves.

2nd Woman--

The voices and the scenery were lively. Thy should we have to lick skeletons?

1st Young Man--

You're right. The sepulcher scene was excellently developed. But

I discovered the Iie when I saw Juliet's feet. They were so very tiny.

2nd Woman--

Delightful! You don't object to that, do you?

Ist Young Man--

Yes, they were too small to be the feet of a woman. They were the

feet of a man... they were feet made by a man.

2nd Woman--

How horrible!

(Murmurings and the sound of swords are heard from inside the theater.)

3rd Woman--

Will we be able to leave?

1st Young llan--

The revolution is arriving at the cathedral at this very moment.

Let's go downstairs. (They leave).

4th student--

The riot began when they saw that Romeo and Juliet really loved each other. 
2nd Student--

Exactly the opposite! The riot began when they saw that they did not love each other, and that they could never love each other. 4th Student--

The Audience is clever enough to see through that! That's why they protested.

2nd Student--

Precisely! The skeletons loved each other and were as pale as flames, but the costumes didn't love each other. At some points the audience could see Juliet's gown covered with repulsive little toads. 4 th Student--

People forget the costumes in a performance. The revolution broke out when they found the real Juliet bound under the seats and gagged with cotton so she couldn't call for help.

\section{1st Young Nan--}

That's the biggest mistake of all! That's why the theater is dying. The audience should cut into the costumes and sets that the poet dreams up in his room. Romeo can be a bird and Juliet can be a stone. Romeo can be a grain of salt and Juliet a map. What does that matter to the audience!

4 th student.--

Nothing, but a bird cannot be a cat and a stone cannot be a raging sea.

2nd Student--

It's a question of form, of masks. A cat can be a frog and the winter moon can easily be a bundle of kindling covered with frozen maggots. The audience must fall asleep over the words; they should not see the sheep that bleat across the column nor the clouds that float across the sky. 
4 th Student--

This is why the revolution has broken out. The stage director opened the trap doors and the people could see how poison from unreal veins had caused the real death of so many young men. It wasn't the players' masks that brought them to life, it was the needle of the barometer they had behind their backs.

2nd Student--

If that's the case, is it necessary for Romeo and Juliet to be a man and a woman for the sepulcher scene to be alive and heartrending?

1st Student--

No it isn't necessary. That was what the stage director was very brilliantly pointing out.

4th Student--

What isn't necessary? Would you stop the machines and sew your grains of wheat in steel?

2nả Student--

What good would that do? They would just sell all the mushrooms, and perhaps the throbbing would be nore intense and passionate. What it comes to is that we know all about growing wheat and nothing about nourishing a mushroom.

5th Student (Leaving the box seats)--

The judge has come, and before they execute them they are going to make them do the sepulcher scene again.

4th Student--

Let's go. You'll see I'm right.

2nd Student--

Yes, let's go.. to see the last truly feminine Juliet that will

ever be seen on stage. (They leave quickly.) 
The Nude--

Father, forgive then for they know not what they do!

The Medic (To the Thieves) $-\infty$

What are you doing here at this hour?

The Thieves $\rightarrow$

The prompter made a mistake.

The Medicm-

Have you had your injections?

The Thieves-m

Yes. (They sit at the foot of the cot with lit candles. The scene darkens into shadows. The Prompter enters.)

The Medicmo

This is a fine time to assemble the cast!

The Prompter--

Please forgurve ne, but Joseph of Arimathea's beard is missing.

The Medic $=$

Is the operating room ready?

The Pronpter--

All we are missing are the candlesticks, the chalice, and the camphorated øil.

The lledic--

Well hurry ap! (The Prompter leaves.)

The Nude--

Are they missing much?

The Iledic--

Very little now. The third bell has already rung; it's time for the emperor to umask Pontius Pilate. 
1st Young $\mathrm{Han}$ (Enters with the women)--

Please! Don't let panic run away with jou.

1st Woman--

It terrifies me getting lost like this, in a theater without any exits,

2nd Woman -

What scared me nost was that cardboard prop of a wolf and the four snakes in the tin bowl.

3rd Woman--

When we climbed up that pile of rubble I thought we had made it, but the backdrops got in the way. I got my gold crepe shoes all spotted with oil too.

4th Woman (Approaching the arches)--

They are going to play the sepulcher scene again. Surely now the doors will be burned dom. A few minutes ago I saw the guards of the doors. Their hands were badly burned and they couldn't control the fire.

Ist Young lian--

We could reach one of the balconies from the branches of that tree and call for help from there.

The Medic (In a low voice)--

When does the cry of anguish begin?

The Thieves (Lifting their candles)--

Holy. Holy. Holy.

The Nude--

Father into your hands I commend my spirit. The Wedic--

You were two minutes early. 
The Nude-w

Because the nightingale had begun to sing already.

The Medic-

That's true. "The drugstores are all open for the anguish.

The Nude-=

For the anguish of one man, on the platforms and trains.

The Medic (Looking at his watch, in a loud voice)--

Bring on the bedsheet. Make sure the wind you raise doesn't blow

your wigs off. Hurry!

The Thieves--

Holy. Holy. Holy.

The Nude--

It is finished.

(The cot tums on its perpendicular axis and the Nude revolves out of sight. On the reverse side of the cot lies the 1st Man wearing evening clothes and a black beard.)

Ist Man (CIosing his eyes)--

Agony!

(The Iighting becones the silvery color of a movie screen. The arches and staimays are lit with a grainy blue light. The Iledic and The Thieves exit dancing, their faces to the audience. The students emerge from one of the arches. They are carrying little flashlights.)

4 th Student--

The audience's attitude has been detestable!

1st Student--

It certainly has! A spectator should never become involved in the drama. When people go to an aquarium they don't assassinate the 
sea serpents or the sea-rats or the fish covered with leprosy.

They just put their eyes to the glass tanks and learn.

4 th student.-

Romeo was a thirty y sar old man and Juliet was a fifteen year old boy. The audience's denunciation was justified.

2nd student.-

The stage director avoided letting the audience knor all that in a very imaginative way, but the horses and the revolution ruined his plans.

4 th Student--

What is really inconceivable is that they have killed him.

1st Student--

And that they have killed the real Juliet who moaned under the orchestra seats.

4th Student--

They killed them out of curiosity, just to see what they had inside them.

3rd Student--

And what has been revealed? A lot of wounds and total chaos. 4th Student--

The repetition of the sepulcher scene was wonderful. They undoubtedly loved each other incalcuably, although I cannot see why. When the nightingale sang I couldn't help but cry.

3rd Student--

No one could, but after that they all rattled their swords and truncheons because the poetry was stronger than they. And when dogma loosens its power it can fearlessly trample down the most innocent of truths. 
5th Student (Joyfully)--

Look! I've got one of Juliet's shoes. I stole it while the nuns were putting a shroud on her.

4 th Student (Seriously) --

Which Juliet?

5th Student--

Well how many Juliet's are there? The one in the play! The one that had the most beautiful feet in the world.

4th Student (With amazement) --

Don't you realize that the Juliet in the tomb was a boy in disguise, a trick of the stage director, and the real JuIiet was bound and gagged beneath the seats?

5th Student (Bursts out laughing)--

That's fine with me! She seemed very beautiful and if she vas a boy in disguise I don't care. On the other hand, I wouldn't have picked up the shoe of that dust covered girl who moaned like a cat under the seats.

3rd Student-a

They have killed her nevertheless.

5th Student--

Because they are crazy; but I don't have time to think about whether she is a man, woman or child. I climb the mountain twice every day when I've finished my studies and tend my enormous herd of bulls which I have to fight and conquer each instant. I only have time to see that I love her with a beautiful love.

1st Student--

Splendid! And what if I want to fall in love with a crocodile? 
5th Student--

Go right ahead!

1st Student--

And what if I want to fall in love with you?

5th Student (Throwing hin the shoe)--

Fall in love with me too, I'II let you! I'Il carry you over the cliffs on my shoulders.

1st student--

And we'll smash everything.

5th Student--

All the rooftops and all the families.

1st Student--

And when they talk of love we'II come in football cleats and throw dirt on the mirrors.

5th Student-o

And we'll bum the book when the priests read the mass.

1st Student--

Let's go! Let's go right away.

5th Student--

I have four hundred bulls. With the ropes my father made we will

hitch them to the boulders and pull them apart and let the volcano erupt.

1st Student--

Joy! Joy to the boys and girls and frogs and little wooden nails!

The Prompter (Entering) --

Gentlemen, the descriptive geometry class.

1st Man--

Oh agony! 
(The stage darkens. The students tum on their flashlights and go in the door of the university.)

The Prompter (Disagreeably) -..

Don't damage the windows!

5th Student (Fleeing through the arches with the 1st Student)--

Joy! Joy! Joy!

1st Wan --

Oh anguish! The solitude of a man in a drearn full of elevators and trains in wich you travel at incredible speeds. The solitude of the buildings and street-comers and beaches where you will never go. Loneliness!

Ist Woman (On the stairs)--

Is this the same stage set again? This is horrible.

1st Young IIan--

One of these doors has to be real.

2no Woman--

Please! Don't let go of my hand!

1st Young Kan--

When dawn cones welll. steer by the skylights.

3rd Woman--

I'm beginning to get cold in these clothes.

1st $\operatorname{Man}$ (In feeble voice)--

Henry! Henry!

1st Woman--

What was that? 
1st Young lian--

Keep calm.

(The stage is in darkness. The lantem of the 1st Young Ian

illuminates the dead face of the 1st Ian.)

Curtain.

End of

"The Audience" 